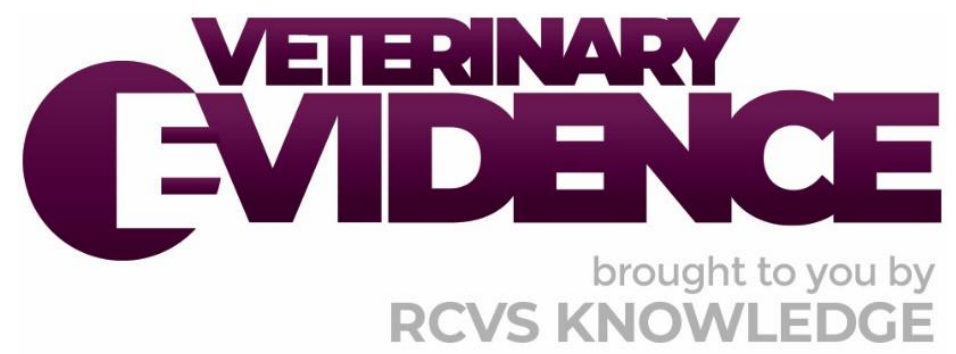

\title{
Does medical or surgical treatment for aortic stenosis improve outcome in dogs?
}

\section{A Knowledge Summary by}

Julia Thomas Student ${ }^{1^{*}}$

Sophie Marshall Student ${ }^{1}$

Georgia Conway Student ${ }^{1}$

Karin Gormley Student ${ }^{1}$

Kieran Borgeat BSc BVSc MVetMed CertVC MRCVS DipACVIM DipECVIM-CA ${ }^{1}$

\footnotetext{
${ }^{1}$ University of Bristol, Bristol Veterinary School, Langford House, Langford, Bristol BS40 5DU

*Corresponding Author (it16942@bristol.ac.uk)
}

ISSN: 2396-9776

Published: 03 Jun 2021

in: The Veterinary Evidence journal Vol 6, Issue 2

DOI: https://doi.org/10.18849/ve.v6i2.368

Reviewed by: Adam Swallow (BVSc MRCVS) and Richard White (BVetMed PhD DVR DipACVS DipECVS DSAS(Soft Tissue) DipACVS FRCVS)

Next Review Date: 11 Apr 2023 


\section{KNOWLEDGE SUMMARY}

\section{PICO question}

In adult dogs with aortic stenosis does treatment with beta blockers compared with surgical intervention show a longer survival time with improved clinical parameters?

\section{Clinical bottom line}

\section{Category of research question}

\section{Treatment}

\section{The number and type of study designs reviewed}

Eight studies were reviewed. One was a randomised controlled study, three were cohort studies, one was a case series and three were case reports

\section{Strength of evidence}

Moderate to weak

\section{Outcomes reported}

Intervention appeared to improve survival times \pm physiological parameters when compared to no treatment at all. The severity of clinical signs was reduced, but the risk of sudden cardiac-related death was not diminished according to a number of papers. The direct comparison of surgical treatment with the use of beta blockers showed no significant difference in survival times or physiological parameters across all papers. There is not enough evidence available comparing the different beta blockers used for treatment to draw a meaningful conclusion as to which is more effective

\section{Conclusion}

Treatment of some form should be given to a dog diagnosed with aortic stenosis. This will improve clinical signs and there is evidence to say that it will prolong survival as well as improve quality of life.

More research into this area is essential. Controlled, randomised clinical trials should be carried out in order to find a reliable and strong recommendation for treatment. Ethical implications need to be considered when going forward with this, which is why the evidence pool is likely to be so limited currently

\section{How to apply this evidence in practice}

\section{Clinical Scenario}

A dog with aortic stenosis is presented for treatment. The owner is keen for long-term survival of their pet and as a clinician you aim to find the best intervention to improve physiologic parameters and quality of life.

\section{The evidence}

A total of eight published articles were evaluated: three cohort studies, three case reports, one case series and one randomised controlled study. 


\section{Summary of the evidence}

\begin{tabular}{|c|c|}
\hline \multicolumn{2}{|l|}{ Eason et al. (2014) } \\
\hline Population: & $\begin{array}{l}\text { Dogs with uncomplicated, severe subaortic stenosis (SAS) diagnosed } \\
\text { via standard transthoracic 2-dimensional and Doppler } \\
\text { echocardiography. }\end{array}$ \\
\hline Sample size: & 50 dogs \\
\hline Intervention details: & $\begin{array}{l}\text { Treatment group } 27 / 50 \text { - received beta-blockers } \\
\text { Control group } 23 / 50 \text { - received no treatment } \\
\text { - Of the } 27 \text { dogs in the treatment group, } 25 \text { received atenolol. } \\
\text { The dose of atenolol was known for } 23 \text { of these dogs. They } \\
\text { received a median dose of } 0.55 \mathrm{mg} / \mathrm{kg} \text { (range } 0.3-1.2 \mathrm{mg} / \mathrm{kg} \text { ) } \\
\text { given orally, once every } 12 \text { hours. } \\
\text { - } 1 / 27 \text { received propranolol at } 0.64 \mathrm{mg} / \mathrm{kg} \text {, given orally, once } \\
\text { every } 8 \text { hours and another dog received sotalol at of } 0.9 \\
\mathrm{mg} / \mathrm{kg} \text { given once orally, every } 12 \text { hours. }\end{array}$ \\
\hline Study design: & Non-blinded, non-randomised, retrospective cohort study \\
\hline Outcome studied: & $\begin{array}{l}\text { Transvalvular pressure gradient (PG), as estimated by Doppler } \\
\text { echocardiography. Severe stenosis was classified as }>80 \mathrm{mmHg} \text {. }\end{array}$ \\
\hline $\begin{array}{l}\text { Main findings: } \\
\text { (relevant to PICO question): }\end{array}$ & $\begin{array}{l}\text { - Treatment with a beta blocker had no demonstratable effect } \\
\text { on survival time. } \\
\text { - Two mortality analyses were carried out; one looking at } 24 \\
\text { dogs from the treatment group and the other at } 14 \text { dogs in } \\
\text { the control group. A high PG ( }>130 \mathrm{mmHg} \text { ) at diagnosis } \\
\text { ( } 20 / 50 \text { dogs) in both analyses was associated with a reduced } \\
\text { survival time of } 2.8 \text { years, compared with } 8.3 \text { years for } \leq 130 \\
\mathrm{mmHg}(30 / 50 \text { dogs). } \\
\text { - An increased age at diagnosis was associated with an } \\
\text { increased survival time in the all-causes multivariate } \\
\text { mortality analysis. }\end{array}$ \\
\hline Limitations: & $\begin{array}{l}\text { Retrospective cohort managed by multiple clinicians, so inherently } \\
\text { biased by lack of standardisation: in decision-making; dose of } \\
\text { medication prescribed, and recommendation for euthanasia. }\end{array}$ \\
\hline
\end{tabular}

Hirao et al. (2003)

\begin{tabular}{|r|r|}
\hline Population: & $\begin{array}{l}\text { A } 3 \text { month old Golden Retriever diagnosed with subvalvular aortic } \\
\text { stenosis }\end{array}$ \\
\hline Sample size: & One dog \\
\hline Intervention details: & $\begin{array}{r}\text { The dog was initially administered isosorbide dinitrate and } \\
\text { dipyridamole but no improvement was seen. }\end{array}$ \\
- Surgical resection of the subvalvular stenosis was therefore \\
undertaken. \\
The stenosis diameter was increased from $8 \mathrm{~mm}$ to $12 \mathrm{~mm}$.
\end{tabular}




\begin{tabular}{|c|c|}
\hline Study design: & Case report \\
\hline Outcome studied: & $\begin{array}{l}\text { Left ventricular systolic pressure, and the grade of the auscultated } \\
\text { heart murmur. }\end{array}$ \\
\hline $\begin{array}{l}\text { Main findings: } \\
\text { (relevant to PICO question): }\end{array}$ & $\begin{array}{l}\text { - } 203 \text { days post-surgery, the dog was re-examined. One of the } \\
\text { tests performed was selective left cardiac catheterisation, } \\
\text { which showed a decrease in left ventricular-aortic systolic } \\
\text { PG from } 90 \text { (pre-operative) to } 44 \mathrm{mmHg} \text {. } \\
\text { - Left ventricular angiocardiography showed an increase in } \\
\text { the diameter of the left ventricular outflow tract } \\
\text { postoperatively. } \\
\text { - The grade of the presenting heart murmur also decreased } \\
\text { from grade V/VI to grade II/VI } 7 \text { months postoperatively. } \\
\text { - The dog died suddenly } 10 \text { months postoperatively, possibly } \\
\text { related to its heart disease. } \\
\text { - The report postulated the benefit of administration of } \\
\text { atenolol prior to surgical intervention, to alleviate } \\
\text { ventricular pressure overload before the myocardium is } \\
\text { damaged irreversibly. The report suggested further research } \\
\text { into this area is needed. }\end{array}$ \\
\hline Limitations: & $\begin{array}{l}\text { - This is a case report and therefore is reporting the response } \\
\text { to treatment of one individual. Outcome here may not be } \\
\text { repeatable amongst other animals. } \\
\text { - There were no defined criteria for how the dog would be } \\
\text { treated before treatment began, it was at the clinician's } \\
\text { discretion as the case progressed. } \\
\text { - Short survival time post-intervention does not allow for } \\
\text { assessment of the utility of this treatment in the long-term. } \\
\text { - No conclusive data can be drawn from this publication. }\end{array}$ \\
\hline
\end{tabular}

Komtebedde et al. (1993)

\begin{tabular}{|c|c|}
\hline Population: & $\begin{array}{l}\text { Dogs with subvalvular SAS that had a systolic PG }>70 \mathrm{mmHg} \text { and no } \\
\text { other clinically significant cardiac defects. } \\
\text { They had clinical signs which led to their referral for surgical } \\
\text { correction; four dogs had systolic apical murmurs and three had } \\
\text { syncope/exercise intolerance. }\end{array}$ \\
\hline Sample size: & Seven dogs \\
\hline Intervention details: & $\begin{array}{l}\text { When referred, patients were receiving a range of non- } \\
\text { standardised medication: five dogs were receiving } \\
\text { propranolol (beta blocker), one furosemide (loop diuretic) } \\
\text { and another quinidine and digoxin (antiarrhythmics). } \\
\text { - Patients underwent cardiopulmonary bypass (CPB) for a } \\
\text { range of 130-210 minutes, as well as a transverse aortotomy } \\
\text { to surgically correct subvalvular SAS. }\end{array}$ \\
\hline Study design: & Case series \\
\hline Outcome studied: & $\begin{array}{l}\text { Haemodynamic parameters and cardiopulmonary data were both } \\
\text { measured pre-operatively, perioperatively and for } 3 \text { days } \\
\text { postoperatively. }\end{array}$ \\
\hline
\end{tabular}




\begin{tabular}{|c|c|}
\hline $\begin{array}{l}\text { Main findings: } \\
\text { (relevant to PICO question): }\end{array}$ & $\begin{array}{l}\text { - Six dogs were alive and stable after a mean follow-up time } \\
\text { of } 15.8 \text { months (range from 2-27 months). } \\
\text { - One dog died of chylothorax, } 4 \text { months postoperatively. } \\
\text { - No dog experienced clinical signs of exercise intolerance or } \\
\text { syncope postoperatively. }\end{array}$ \\
\hline Limitations: & $\begin{array}{l}\text { - The study had a small sample size, and no control group with } \\
\text { which to compare treatment efficacy. } \\
\text { - It is possible that the population suffered selection or } \\
\text { referral bias due to the specific inclusion criteria in referred } \\
\text { animals. } \\
\text { - There was variation in medication administered prior to } \\
\text { surgery. This makes it harder to evaluate the effectiveness of } \\
\text { these medications, used alone or prior to surgery. }\end{array}$ \\
\hline
\end{tabular}

Meurs et al. (2005)

\begin{tabular}{|c|c|}
\hline Population: & $\begin{array}{l}\text { Large breed dogs }<24 \text { months old with severe subaortic stenosis. } \\
\text { Newfoundlands were actively recruited. }\end{array}$ \\
\hline Sample size: & 38 dogs \\
\hline Intervention details: & $\begin{array}{l}\text { BAV group }-15 / 28 \text { dogs } \\
\text { Atenolol group - } 13 / 28 \\
\text { - } 10 / 38 \text { dogs were used to investigate the feasibility of the } \\
\text { standard balloon valvuloplasty (BAV) surgery (not included } \\
\text { for analysis of technique efficacy). } \\
\text { - } 28 / 38 \text { dogs were enrolled in the long-term follow-up study. } \\
\text { - The dosage of atenolol provided ranged from } 0.46-1.5 \\
\text { - } \mathrm{mg} / \mathrm{kg} \text {, given orally once every } 12 \text { hours. } \\
\text { - The group of } 28 \text { dogs in the long-term follow-up study were } \\
\text { re-assessed periodically throughout life. }\end{array}$ \\
\hline Study design: & Randomised, non-blinded prospective study \\
\hline Outcome studied: & $\begin{array}{l}\text { The PG of all the dogs was measured pre-intervention and } 6 \text { weeks } \\
\text { after intervention (i.e. either } 6 \text { weeks post-surgery or after } 6 \text { weeks } \\
\text { of atenolol treatment). }\end{array}$ \\
\hline $\begin{array}{l}\text { Main findings: } \\
\text { (relevant to PICO question): }\end{array}$ & $\begin{array}{l}\text { - The BAV group (15/28) had a mean pre-operative PG of } 147 \\
\mathrm{mmHg} \text {, reduced to } 86.7 \mathrm{mmHg} \text { post-surgery. } \\
\text { - The atenolol group of } 13 \mathrm{dogs} \text { had a pre-treatment PG of } \\
122.2 \mathrm{mmHg} \text {, reduced to } 113 \mathrm{mmHg} \text { after } 6 \text { weeks of } \\
\text { atenolol. } \\
\text { - The median survival time of the dogs treated with surgery } \\
\text { and those treated medically were almost identical; } 55 \\
\text { months vs. } 56 \text { months, respectively. }\end{array}$ \\
\hline Limitations: & $\begin{array}{l}\text { - Selection bias: Newfoundland dogs were overrepresented } \\
\text { amongst the study population, owing to active recruitment } \\
\text { of this breed. } \\
\text { - There was no negative control group (due to ethical } \\
\text { implications of not treating dogs with severe disease) and }\end{array}$ \\
\hline
\end{tabular}




\begin{tabular}{|l|l|}
\hline & $\begin{array}{l}\text { therefore the difference made by either intervention to the } \\
\text { 'natural' survival time cannot be accurately determined. }\end{array}$ \\
\hline
\end{tabular}

\begin{tabular}{|c|c|}
\hline \multicolumn{2}{|l|}{ Muir et al. (1989) } \\
\hline Population: & $\begin{array}{l}4 \text { month old St. Bernard. } \\
\text { Presented with a grade V/VI murmur and severe aortic stenosis. }\end{array}$ \\
\hline Sample size: & One dog \\
\hline Intervention details: & $\begin{array}{l}\text { - The dog was diagnosed with severe aortic stenosis on } \\
\text { echocardiography. } \\
\text { - Treatment was begun with } 0.3 \mathrm{mg} / \mathrm{kg} \text { propranolol, and this } \\
\text { was gradually increased to } 1.0 \mathrm{mg} / \mathrm{kg} \text {. } \\
\text { - A balloon dilation was then attempted to relieve the } \\
\text { stenosis. } \\
\text { - The dog then underwent surgical resection of the stenosis, } \\
10 \text { days after the balloon dilation. } \\
\text { - Propranolol was maintained postoperatively. }\end{array}$ \\
\hline Study design: & Case report \\
\hline Outcome studied: & $\begin{array}{l}\text { Systolic PG across the stenosis, derived by Doppler } \\
\text { echocardiography }\end{array}$ \\
\hline $\begin{array}{l}\text { Main findings: } \\
\text { (relevant to PICO question): }\end{array}$ & $\begin{array}{l}\text { - When the aortic stenosis was diagnosed, the systolic PG } \\
\text { across the stenosis was } 100 \mathrm{mmHg} \text {. } \\
\text { - Post balloon dilation, the PG across the stenosis was similar, } \\
\text { at } 90 \mathrm{mmHg} \text {. } \\
\text { - As a result, surgery was performed to resect the stenotic } \\
\text { region. } \\
\text { - } 48 \text {-hours after surgery, the heart murmur, whilst still easily } \\
\text { audible, had reduced in intensity. } \\
\text { - The dog died } 20 \text { days postoperatively. Post-mortem } \\
\text { determined that death was not directly related to the } \\
\text { surgery, but still may have been cardiac in origin. Repeat } \\
\text { echocardiography was therefore never performed. }\end{array}$ \\
\hline Limitations: & $\begin{array}{l}\text { - This is a case report and therefore is reporting the response } \\
\text { to treatment of one individual. Outcome here may not be } \\
\text { repeatable amongst other animals. } \\
\text { - Short survival time post-intervention does not allow for } \\
\text { assessment of the utility of this treatment in the long-term. } \\
\text { - The dog underwent many interventions, so the individual } \\
\text { effectiveness of each cannot be determined. } \\
\text { - The authors have not stated for how long the dog received } \\
\text { medical treatment prior to undergoing surgical intervention. } \\
\text { No conclusive data can be drawn from this publication. }\end{array}$ \\
\hline
\end{tabular}




\begin{tabular}{|c|c|}
\hline \multicolumn{2}{|l|}{ Nelson et al. (2004) } \\
\hline Population: & $\begin{array}{l}10 \text { month old Golden Retriever presenting with grade } V / \mathrm{VI} \text { heart } \\
\text { murmur, systolic PG of } 159 \mathrm{mmHg} \text {, diagnosed with severe subaortic } \\
\text { stenosis. }\end{array}$ \\
\hline Sample size: & One dog \\
\hline Intervention details: & $\begin{array}{l}\text { - The dog was diagnosed with severe aortic stenosis, using } \\
\text { echocardiography, and initially treated with } 0.8 \mathrm{mg} / \mathrm{kg} \\
\text { atenolol, given orally once every } 12 \text { hours. } \\
\text { - } 11 \text { months after presentation, the systolic PG had increased } \\
\text { to } 240 \mathrm{mmHg} \text {, but the atenolol dosage was deemed } \\
\text { adequate and not altered. } \\
\text { - } 1 \text { year later the dog presented with clinical signs of exercise } \\
\text { intolerance and syncope; PG remained the same. } \\
\text { - Surgery was performed; a modified Konno procedure, } \\
\text { involving the complete removal of the affected area of } \\
\text { septal outflow tract via right ventriculotomy. } \\
\text { - A permanent intra-abdominal pacemaker was inserted } \\
\text { because of potential damage to the atrioventricular node. } \\
\text { - Postoperative ventricular arrhythmias were present and } \\
\text { treated with amiodarone. This resolved after } 8 \text { days. }\end{array}$ \\
\hline Study design: & Case report \\
\hline Outcome studied: & Systolic PG across the stenosis. \\
\hline $\begin{array}{l}\text { Main findings: } \\
\text { (relevant to PICO question): }\end{array}$ & $\begin{array}{l}\text { - } 8 \text { days postoperatively, the systolic PG had reduced to } 78 \\
\mathrm{mmHg} \text {. } \\
\text { - This decreased further after } 24 \text { months to } 40 \mathrm{mmHg} \text {. }\end{array}$ \\
\hline Limitations: & $\begin{array}{l}\text { - This is a case report and therefore is reporting the response } \\
\text { to treatment of one individual. Outcome here may not be } \\
\text { repeatable amongst other animals. } \\
\text { - A } 2 \text { year follow-up post-intervention does not allow for } \\
\text { assessment of the utility of this treatment in the long-term. } \\
\text { - No conclusive data can be drawn from this publication. }\end{array}$ \\
\hline
\end{tabular}

Orton et al. (2000)

\begin{tabular}{|r|l|}
\hline Population: & $\begin{array}{l}\text { Dogs diagnosed with subvalvular aortic stenosis with instantaneous } \\
\text { systolic } \mathrm{PG}>50 \mathrm{mmHg} \text { and known survival outcomes. }\end{array}$ \\
\hline Sample size: & 44 dogs \\
\hline Intervention details: & $\begin{array}{c}\text { The } 44 \text { dogs were divided into two groups; } \\
\text { Surgical group 22/44 } \\
\text { Non-surgical group 22/44 } \\
\text { All dogs in the surgery group were administered long-term } \\
\text { atenolol, as were all but three dogs in the non-surgical } \\
\text { group. The dosage range of atenolol was } 0.7-1.2 \mathrm{mg} / \mathrm{kg}, \\
\text { given orally, once every } 24 \text { hours. } \\
\text { The surgery group had undergone open surgical correction } \\
\text { of the subaortic stenosis with the aid of cardiopulmonary }\end{array}$ \\
\end{tabular}




\begin{tabular}{|c|c|}
\hline & $\begin{array}{l}\text { bypass. All } 22 \text { dogs underwent a membranectomy; of these, } \\
14 \text { underwent a concurrent quadratic septal myectomy in } \\
\text { addition (dependent on degree of myocardial hypertrophy). }\end{array}$ \\
\hline Study design: & Non-blinded, non-randomised retrospective cohort study \\
\hline Outcome studied: & Systolic PG. \\
\hline $\begin{array}{l}\text { Main findings: } \\
\text { (relevant to PICO question): }\end{array}$ & $\begin{array}{l}\text { - There was no significant difference in the early reduction of } \\
\text { PG between the two groups. In the surgery group, the PG } \\
\text { range was } 54-232 \mathrm{mmHg} \text {, and in the non-surgical group the } \\
\text { PG range was } 51-272 \mathrm{mmHg} \text {. } \\
\text { - At } 2-4 \text { months postoperatively, for the surgery group the } \\
\text { systolic PG was significantly lower, at } 22-100 \mathrm{mmHg} \text {. This } \\
\text { equates to a } 41-75 \% \text { reduction. There is no comparative } \\
\text { data reported for the non-surgical group. } \\
\text { - The addition of a septal myectomy performed alongside the } \\
\text { membranectomy documented no further systolic PG } \\
\text { reduction, nor an altered survival time compared to those } \\
\text { who had not undergone this additional surgery. } \\
\text { - In the surgery group, } 5 / 22 \text { dogs had recorded deaths related } \\
\text { to surgical complications, and a further } 6 / 22 \text { recorded } \\
\text { because of the disease itself (total } 11 / 22 \text { cardiac related } \\
\text { deaths). } \\
\text { - In the non-surgical group, } 11 / 22 \text { cardiac related deaths were } \\
\text { also recorded. } \\
\text { No benefit to survival was documented between surgical } \\
\text { and medical intervention. } \\
\text { The paper suggests a benefit in the use of atenolol to treat } \\
\text { when compared with no treatment, due to overall longer } \\
\text { survival times in dogs in this study, when compared to those } \\
\text { of another study (Kienle et al. } 1994 \text { ) who did not receive } \\
\text { atenolol. However, there was no negative control group in } \\
\text { this comparison. }\end{array}$ \\
\hline Limitations: & $\begin{array}{l}\text { - There was no negative control group with which to compare } \\
\text { the effects of these two treatment options, and the authors } \\
\text { suggest a controlled clinical study to investigate this } \\
\text { hypothesis may be warranted. } \\
\text { - The reliability of the results was affected by the fact that this } \\
\text { was a retrospective study and therefore nothing was } \\
\text { performed under controlled conditions. } \\
\text { - No follow-up echocardiographic data was available from the } \\
\text { atenolol treatment group; therefore we cannot say that } \\
\text { surgery was any better than medical management based on } \\
\text { this data. }\end{array}$ \\
\hline
\end{tabular}

Shen et al. (2017)

Population: Dogs with severe SAS with a mean transvalvular PG of $143 \mathrm{mmHg}$ (ranging $80-332 \mathrm{mmHg}$ ) that had undergone combined cutting and high-pressure balloon valvuloplasty (CB/HPBV). 


\begin{tabular}{|c|c|}
\hline Sample size: & 22 dogs \\
\hline Intervention details: & $\begin{array}{l}\text { - Angiographic and echocardiographic video loops were } \\
\text { collected within the } 24 \text { hours prior to intervention. } \\
\text { Screenshots were taken during diastole (in right-sided } \\
\text { parasternal long-axis view) and measured for aortoseptal } \\
\text { angle (AoSA) - an assessment of how steep the angle of left } \\
\text { ventricular outflow is, previously associated with severity of } \\
\text { subaortic stenosis. } \\
\text { - A PG measurement was taken by direct cardiac } \\
\text { catheterisation in anaesthetised animals before and } \\
\text { immediately after CB/HPBV, and measured by Doppler } \\
\text { echocardiography at diagnosis, then again } 24 \text { hours, } 6 \\
\text { months and } 12 \text { months post-procedure. } \\
\text { All dogs were treated with atenolol when images were } \\
\text { acquired (Atenolol dose regimen was adapted to suit the } \\
\text { individual needs of each dog and was not standardised. The } \\
\text { authors have not provided the individual dosages). }\end{array}$ \\
\hline Study design: & Blinded, non-randomised retrospective cohort study \\
\hline Outcome studied: & PG change over time, survival data \\
\hline $\begin{array}{l}\text { Main findings: } \\
\text { (relevant to PICO question): }\end{array}$ & $\begin{array}{l}\text { - Dogs with an obtuse AoSA }>160^{\circ}(4 / 22) \text { had a greater } \\
\text { decrease in PG following } \mathrm{CB} / \mathrm{HPBV} \text { compared to those with a } \\
\text { more acute AoSA }\left(<160^{\circ}-18 / 22 \text { dogs). }\right. \\
\text { - At } 24 \text { hours post-procedure, } \mathrm{PG} \text { reduction was } 54 \mathrm{mmHg} \text { in } \\
\text { dogs with obtuse AoSA. Reduction was lower, at } 40 \mathrm{mmHg} \text { in } \\
\text { the acute AoSA group. } \\
\text { - At } 6 \text { months, in dogs with obtuse AoSA PG remained at a } \\
\text { reduction of } 58 \mathrm{mmHg} \text {, compared to } 28 \mathrm{mmHg} \text { in acute } \\
\text { AoSA dogs. } \\
\text { - By } 12 \text { months, PG was reduced by } 76 \mathrm{mmHg} \text { in dogs with } \\
\text { obtuse AoSA vs. } 28 \mathrm{mmHg} \text { acute AoSA. } \\
\text { This suggests that dogs with an obtuse AoSA may benefit } \\
\text { more and for longer by undergoing a CB/HPBV procedure } \\
\text { than those with an acute }\left(<160^{\circ}\right) \text { AoSA. }\end{array}$ \\
\hline Limitations: & $\begin{array}{l}\text { - All dogs were treated with atenolol when images were } \\
\text { acquired. As the study was retrospective, there was no } \\
\text { control over dosage and compliance. } \\
\text { No control group of atenolol only or negative control group } \\
\text { was used as a comparator. }\end{array}$ \\
\hline
\end{tabular}

\section{Appraisal, application and reflection}

The weakest level of evidence was provided by three case reports (Hirao et al., 2003; Muir et al., 1989; and Nelson et al., 2004), as each of these involved only one animal. Papers with a larger sample size (Eason et al., 2014; and Orton et al., 2000) were more valuable, but often limited by a retrospective design (Shen et al., 2017; and Orton et al., 2000). This leads to inherent bias because of no standardisation in decision-making, testing or treatment with historic clinical cases, and the involvement of random factors, such as owner opinion and financial influences. However, publications spanning the period 1989-2017 all used comparable surgical procedures and medical treatment, despite the lengthy time frame. All found similar results - that some sort 
of treatment likely benefits dogs with aortic stenosis - and suggested further research is indicated and required to determine which treatment option is the most effective to improve quality of life and prolong survival.

\section{Methodology Section}

\begin{tabular}{|c|c|}
\hline \multicolumn{2}{|l|}{ Search Strategy } \\
\hline $\begin{array}{r}\text { Databases searched and dates } \\
\text { covered: }\end{array}$ & $\begin{array}{l}\text { CAB Abstracts (Ovid SP): 1973-2021, week } 13 \\
\text { Medline (Ovid SP): 1946-present }\end{array}$ \\
\hline Search terms: & $\begin{array}{l}\text { CAB Abstracts: } \\
\text { (canine OR canines OR dog*).mp } \\
\text { AND } \\
\text { (aortic stenosis OR aortic valve stenosis).mp } \\
\text { AND } \\
\text { (Atenolol OR "beta blockers" OR "beta-blockers" OR propranolol OR } \\
\text { "surgical correction" OR surgical OR surg* OR "balloon } \\
\text { valvuloplasty").mp } \\
\text { AND } \\
\text { (Outcome OR survival OR "survival time" OR management OR } \\
\text { result).mp } \\
\text { Medline: } \\
\text { (Canine OR Canines OR Dog*).mp } \\
\text { AND } \\
\text { (aortic stenosis OR "aortic valve stenosis").mp } \\
\text { AND } \\
\text { (Atenolol OR "beta blockers" OR "beta-blockers "OR propranolol OR } \\
\text { "surgical correction" OR surgical OR surg* OR "balloon } \\
\text { valvuloplasty").mp } \\
\text { AND } \\
\text { (Outcome OR survival OR "survival time" OR result).mp }\end{array}$ \\
\hline Dates searches performed: & 11 Apr 2021 \\
\hline
\end{tabular}

\section{Exclusion / Inclusion Criteria}

\begin{tabular}{|c|c|}
\hline Exclusion: & $\begin{array}{l}\text { - Discussion of surgical method without focus on individual } \\
\text { - Discussion of the progression of aortic stenosis as a disease } \\
\text { - } \text { without focus on treatment methods } \\
\text { - treatment that could influence outcome } \\
\text { - latrogenically created aortic stenosis } \\
\text { - Irrelevance to PICO question } \\
\text { - Full text inaccessible }\end{array}$ \\
\hline Inclusion: & $\begin{array}{l}\text { - Available in English } \\
\text { - Aortic stenosis treated with any surgical intervention or } \\
\text { atenolol or propranolol }\end{array}$ \\
\hline
\end{tabular}




\begin{tabular}{|c|c|c|c|c|c|c|c|c|c|}
\hline \multicolumn{10}{|c|}{ Search Outcome } \\
\hline Database & $\begin{array}{l}\text { Number } \\
\text { of } \\
\text { results }\end{array}$ & $\begin{array}{c}\text { Excluded - } \\
\text { Concurrent } \\
\text { or } \\
\text { secondary } \\
\text { disease }\end{array}$ & $\begin{array}{l}\text { Excluded - } \\
\qquad \text { Not } \\
\text { available in } \\
\text { English }\end{array}$ & $\begin{array}{l}\text { Excluded - } \\
\text { Describes } \\
\text { surgical } \\
\text { method, not } \\
\text { outcomes }\end{array}$ & $\begin{array}{c}\text { Excluded - } \\
\text { Focused on aortic } \\
\text { stenosis as a } \\
\text { disease, not on } \\
\text { treatment } \\
\text { methods }\end{array}$ & $\begin{array}{l}\text { Excluded - } \\
\text { Iatrogenic } \\
\text { aortic } \\
\text { stenosis }\end{array}$ & $\begin{array}{l}\text { Excluded - } \\
\text { Not animals }\end{array}$ & $\begin{array}{l}\text { Excluded - } \\
\text { Irrelevant to } \\
\text { PICO question }\end{array}$ & $\begin{array}{c}\text { Total } \\
\text { relevant } \\
\text { papers }\end{array}$ \\
\hline $\begin{array}{l}\mathrm{CAB} \\
\text { Abstracts }\end{array}$ & 10 & 2 & 1 & 3 & 0 & 0 & 0 & 0 & 4 \\
\hline Medline & 24 & 2 & 1 & 5 & 1 & 1 & 1 & 7 & 6 \\
\hline \multicolumn{9}{|c|}{ Total relevant papers when duplicates removed } & 4 \\
\hline
\end{tabular}




\section{CONFLICT OF INTEREST}

The authors declare no conflict of interest.

\section{REFERENCES}

1. Eason, B.D., Fine, D.M., Leeder, D., Stauthammer, C., Lamb, K. \& Tobias, A.H. (2014). Influence of Beta Blockers on Survival in Dogs with Severe Subaortic Stenosis. Journal of Veterinary Internal Medicine. 28(3), 857-862. DOI: http://dx.doi.org/10.1111/jvim.12339

2. Hirao, H., Hoshi K., Kobayashi M., Shimizu, M., Shimamura, S., Tanaka, R., Machida, N., Maruo, K. \& Yamane, Y. (2003). Surgical Correction of Subvalvular Aortic Stenosis Using Cardiopulmonary Bypass in a Dog. The Journal of Veterinary Medical Science. 66(5), 559-562.

DOI: http://dx.doi.org/10.1292/jvms.66.559

3. Kienle, R.D., Thomas, W.P. \& Pion, P.D. (1994). The Natural Clinical History of Canine Congenital Subaortic Stenosis. Journal of Veterinary Internal Medicine. 8(6), 423-431.

DOI: http://dx.doi.org/10.1111/i.1939-1676.1994.tb03262.x

4. Komtebedde, J., Ilkiw, J.E., Follette, D.M., Breznock, E.M. and Tobias, A.H. (1993). Resection of Subvalvular Aortic Stenosis Surgical and Perioperative Management in Seven Dogs. Veterinary Surgery. 22(6), 419-430. DOI: http://dx.doi.org/10.1111/i.1532-950X.1993.tb00417.x

5. Meurs, K.M., Lehmkuhl, L.B. \& Bonagura, J.D. (2005). Survival times in dogs with severe subvalvular aortic stenosis treated with balloon valvuloplasty or atenolol. Journal of the American Veterinary Medical Association. 227(3), 420-424. DOI: http://dx.doi.org/10.2460/javma.2005.227.420

6. Muir, G.D., Panciera, D.L., Fowler, D., Bharadwaj, B.B. \& Burrows, P. (1989). Medical and Surgical Management of Aortic Stenosis in a Dog. Canadian Veterinary Journal. 30(11), 894-896.

7. Nelson, D.A., Fossum, T.W., Gordon, S., Miller, M.W., Felger, M.C., Mertens, M.M., McMichael, M., Nelson, K.T. \& Pahl, G. (2004). Surgical Correction of Subaortic Stenosis via Right Ventriculotomy and Septal Resection in a Dog. Journal of American Veterinary Medical Association. 225(5), 705-708. DOI: http://dx.doi.org/10.2460/javma.2004.225.705

8. Orton, E.C., Herndon G.D., Boon J.A., Gaynor J.S., Hackett T.B. \& Monnet E. (2000). Influence of open surgical correction on intermediate-term outcome in dogs with subvalvular aortic stenosis: 44 cases (1991-1998). Journal of American Veterinary Medical Association. 216(3), 364-367.

DOI: https://doi.org/10.2460/javma.2000.216.364

9. Shen, L., Estrada, A.H., Côté, E., Powell, M.A., Winter, B. \& Lamb, K. (2017). Aortoseptal angle and pressure gradient reduction following balloon valvuloplasty in dogs with severe subaortic stenosis. Journal of Veterinary Cardiology. 19(2), 144-152.

DOI: https://doi.org/10.1016/j.jvc.2016.10.005 


\section{EVIIDEFeE

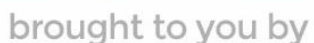 \\ RCVS KNOWLEDGE}

\section{Intellectual Property Rights}

Authors of Knowledge Summaries submitted to RCVS Knowledge for publication will retain copyright in their work, and will be required to grant RCVS Knowledge a non-exclusive license of the rights of copyright in the materials including but not limited to the right to publish, re-

publish, transmit, sell, distribute and otherwise use the materials in all languages and all media throughout the world, and to license or permit others to do so.

\section{Disclaimer}

Knowledge Summaries are a peer-reviewed article type which aims to answer a clinical question based on the best available current evidence. It does not override the responsibility

of the practitioner. Informed decisions should be made by considering such factors as individual clinical expertise and judgement along with patient's circumstances and owners' values. Knowledge Summaries are a resource to help inform and any opinions expressed within the Knowledge Summaries are the author's own and do not necessarily reflect the view of the RCVS Knowledge. Authors are responsible for the accuracy of the content. While the

Editor and Publisher believe that all content herein are in accord with current recommendations and practice at the time of publication, they accept no legal responsibility

for any errors or omissions, and make no warranty, express or implied, with respect to material contained within.

For further information please refer to our Terms of Use.

RCVS Knowledge is the independent charity associated with the Royal College of Veterinary Surgeons (RCVS). Our ambition is to become a global intermediary for evidence based veterinary knowledge by providing access to information

that is of immediate value to practicing veterinary professionals and directly contributes to evidence based clinical decision-making.

https://www.veterinaryevidence.org/

RCVS Knowledge is a registered Charity No. 230886.

Registered as a Company limited by guarantee in England and Wales No. 598443.

Registered Office: Belgravia House, 62-64 Horseferry Road, London SW1P 2AF

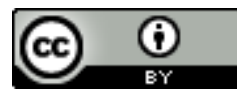

This work is licensed under a Creative Commons Attribution 4.0 International License 